\title{
CAP Reform 1999: A Crisis in the Making?
}

\author{
Robert W. Ackrill ${ }^{1}$ \\ University of Leicester
}

\begin{abstract}
In March 1999, European Agriculture Ministers reformed the CAP. Two weeks later, the European Council amended this reform in order to contain budget costs. Under French pressure, this was achieved by partially reversing the first reform. This paper examines the pressures shaping the 1999 reforms. The second agreement has failed to prepare the CAP for EU enlargement, WTO negotiations and the containment of budget costs. In the light of this, future reform options are considered. It is argued that prices must be cut further, whilst the phased reduction of direct payments will contain budget costs effectively.
\end{abstract}

\footnotetext{
${ }^{1}$ The author is indebted to the editor and anonymous referees for comments that proved tremendously useful in helping to improve the paper. All remaining shortcomings remain his fault alone.
} 


\section{Introduction}

In March 1999 the European Council, meeting in Berlin, agreed a reform of the Common Agricultural Policy (CAP) which superseded a deal the Ministers of Agriculture agreed - or thought they had agreed -two weeks earlier. This paper seeks an explanation of the nature of the second reform, before indicating briefly why further reform will be needed. In suggesting possible directions for reform, three options discussed but not agreed upon during negotiations are examined: degressivity (the reduction over time of direct payments), co-financing (sharing CAP budget costs between EU and national budgets) and modulation (targeting support towards smaller farms). Degressivity offers the best way of containing budget costs. Accompanied by the elimination of price support, this will facilitate agreement in international trade talks and accommodate enlargement.

\section{The Background to the 1999 Reform}

In 1992 a CAP reform was agreed that reduced support prices and export subsidies and introduced or extended direct payments to farmers, driven by the need to cut trade-distorting agricultural policies in the GATT Uruguay Round. As a result, arable sector spending rose from 10.4 billion ECU in 1992 to 17.5 billion ECU in 1997, pushing total CAP guarantee spending from 31.4 billion ECU in 1992 to 40.7 billion ECU in 1997. This rise is an inevitable consequence of replacing support based on high (consumer) prices with direct (taxpayer) payments from the EU budget. ${ }^{2}$

Certain features of the negotiations in 1992 and 1993 included Germany

\footnotetext{
${ }^{2}$ Details of the 1992 CAP reform and the 1993 GATT agreement can be found in, inter alia, Swinbank 1993, Ingersent et al 1998, Kay 1998, Meunier 1998, Coleman and Tangermann 1999 and Daugbjerg 1999.
} 
resolutely opposing price cuts, only agreeing to the 1992 reform when it became clear a continued 'stabilizer' policy would generate large uncompensated price cuts (Kay, 1998, page 124). France was the least reform minded country and, having agreed to the 1992 reform, ensured the GATT agreement left the new CAP unchanged (Meunier, 1998). Third, in seeking compromise to broker agreement, the chair (Portugal) removed elements of the proposal that would have been to its benefit. Aspects of all these features entered the 1999 reform process.

The 1999 reform was also conducted under pressure from several sources. The Uruguay Round imposed ceilings on subsidised EU export volumes (25.2 million tonnes in 2000/01 for cereals, including 14.4 million tonnes of wheat). If the exportable surplus exceeds this, additional quantities may well be sold into intervention. European Commission (1995) suggests the EU15 cereals balance could exceed 40 million tonnes in 2005, reaching nearly 55 million tonnes in 2010. Including the 10 applicant countries of Central and Eastern Europe, the figures are nearly 49 million tonnes and 65 million tonnes respectively. The EU is, therefore, likely to reach the limit on subsidised export volumes, especially if the OECD forecast of weak world markets over the next two years proves correct.

Moreover, the Millennium Round of World Trade Organisation (WTO) talks will examine the continued use of export subsidies and other countries are expected to demand the EU eliminate the remaining links between support payments and production. Ultimately, the Agenda 2000 reforms were motivated by EU enlargement. There is concern that extending an unreformed CAP to several new member states with large agricultural sectors will prove prohibitively expensive for the EU budget. 


\section{CAP Reform 1999}

The reforms of March 1999 followed those of 1992 by continuing to replace high prices with direct payments. Initially, the Ministers of Agriculture cut cereals intervention prices by 20\%, with direct payments increased to offset half of this. Payments for oilseeds and linseed were cut to fall in line with cereals payments and for protein crops, payments were cut but a small premium retained over other crops. Set-aside was retained in principle, but the rate normally set at zero. These changes would be phased in - over two years for the cereals price and set aside changes, three for the oilseeds changes. In the beef sector, prices were cut by $20 \%$, with direct payments increased for bulls (by 55\%), steers and suckler cows (both 38\%). In the dairy sector, a 15\% cut in the intervention price, a direct payment per tonne (of quota) and an increase in quota were agreed. Most countries will get $1.5 \%$ more quota, but Greece, Spain, Italy, Ireland and Northern Ireland were granted additional increases, giving a total increase of $2.4 \%$.

The original proposal foresaw CAP guarantees costing euro 312.5 billion over the period to 2006. In late February 1999, the European Council imposed a lower figure of euro 40.5 billion per year or euro 283.5 billion over 2000-2006. When adjusted to allow spending to rise in line with inflation of $2 \%$ a year, this gave a real terms limit of euro 307.1 billion. This was labelled 'stabilised' expenditure. The first agreement was, however, expected to cost euro 289.3 billion (in nominal terms). The Commission felt further changes were 'unlikely' as the limit was exceeded by just $2 \%$, but EU foreign ministers indicated they would need to 'fine-tune' the deal.

This came two weeks later, when the European Council reached a second agreement. The only significant change for dairy was to delay the introduction of the reforms to 2005/06. For beef, changes were made to intervention arrangements. The 
main changes were made to the arable sector reform. First, the cereals intervention price cut was reduced to $15 \%$, meaning smaller increases in cereals direct payments and larger cuts in the payments for other arable crops (except protein crops, increasing the premium). Also, the 'normal' set aside rate was raised to $10 \%$. German Chancellor Gerhard Schröder felt the second agreement would still breach the spending limit, however, and Günther Verheugen, then German deputy foreign minister, conceded further reform would be needed before 2006, especially given the smaller price cut.

During negotiations, cost cutting alternatives had been discussed but not agreed upon. The need for further reform, elaborated on below, indicates inappropriate policy choices were made. The remaining sections explore the debate leading to the final agreement and how the reform options not adopted could help prepare the CAP for the pressures that lie ahead.

\section{From Agenda 2000 to the Second Agreement}

The 1997 Agenda 2000 proposals were criticised by the UK, Denmark and Sweden as inadequate, whereas Germany was opposed outright to reform, ${ }^{3}$ as were Ireland and Spain. Italy joined the UK, Sweden and Denmark (the 'Gang of Four' or the 'London Club') to call for the abolition of dairy quotas by 2006. Campaigning against this was France. In the beef sector, several countries wanted intervention retained, including Austria, Spain and Finland. There were also divisions over higher beef payments. The UK, France, Ireland and Portugal, with larger extensive herds, were expected to benefit more than countries like Germany, Italy and the Netherlands, whose share of beef production exceeded their share of payments. In the arable sector, the UK, Denmark and Sweden wanted to end set aside. Belgium, Germany and Spain wanted

\footnotetext{
3 The Economist, 6 September 1997.
} 
full compensation for price cuts.

For several countries, these positions reflect their EU budget status. Three countries opposing change from the outset - France, Ireland and Spain - do well from CAP spending. Germany, the UK, the Netherlands, Sweden and Austria all complained about their net contributions. For them, CAP reform cannot be divorced from financial restraint. Although Germany's net contribution is by far the largest (euro 11.2 billion in 1997, with the second largest figure of euro 2.4 billion coming from the Netherlands), when expressed as a percentage of GNP, net contributions are $0.6 \%$ for Germany and Sweden, $0.4 \%$ for Austria, $0.16 \%$ for the UK, but $0.7 \%$ for the Netherlands. Germany's position is complicated, however, by opposition to significant CAP reform. Strong farm unions have ensured successive governments opposed price cuts, promoting policies such as set-aside instead.

Prior to the first agreement the Commission, in seeking compromise, suggested changes to the allocation of dairy quota and phasing in the arable reforms, which were accepted. Germany proposed reducing the depth of price cuts, to $10 \%$ for cereals and $20 \%$ for beef, but the Commission felt this was 'totally unacceptable'. Although this was expected to save about euro 16.6 billion over the period to 2006, it would reduce the effectiveness of the reform too much.

Following the first 'agreement', it became clear very quickly that the French believed an agreement had not been concluded, even though 'France was among countries judged to have done well out of the compensation arrangements' in the first agreement. ${ }^{4}$ Jean Glavany, the French minister, indicated 'notable advances' had been made, but the ‘decision' was an informal qualified majority vote based on national

\footnotetext{
${ }^{4}$ Financial Times, 12 March 1999. For simplicity, the current paper refers to the first and second agreements, the French argument notwithstanding.
} 
negotiating positions. Compromise would be needed to bring Germany and France closer together, but this would be difficult since Germany, with the Commission, had given ground in reaching the first agreement. Moreover, the French delegation in Berlin would be led by President Chirac. He was sympathetic to the concerns of French farmers and was needing to boost his popularity at home. ${ }^{5}$ The Berlin summit thus offered France the opportunity to force further compromise on CAP reform, although other circumstances also assisted France.

First, since replacing price support with direct payments increases budget costs, a (partial) reversal of the first agreement would satisfy the French desire for minimal change and also limit the rise in budget costs. More generally, however, the recent resignation of the Commission, Gerhard Schröder needing to present himself as a strong leader following domestic difficulties and crisis in Kosovo all meant the European Council needed agreement to show unity, resolve and leadership.

Another factor, given the need to close the gap between France and Germany, is the role of the chair in reform negotiations. Several past CAP reforms have seen the country in the chair compromise their own position in the search for agreement. Germany was in the chair for the 'stabilizers' agreement in 1988, which introduced automatic price cuts despite German opposition and in 1992, Portugal removed most elements of modulation in the search for agreement. ${ }^{6}$ In 1997, Germany had opposed reform under Agenda 2000, but by 1999 was pushing for a budget limit 'in an effort

\footnotetext{
${ }^{5}$ Keesing's Record of World Events, May 1998 (vol. 44, no. 5, page 42290) suggests that Chirac’s proposal of Trichet as head of the European Central Bank followed criticisms that he was "not doing enough to counter German influence in Europe”. Such statements were not helpful given the need for compromise between France and Germany.

${ }^{6}$ This changed the reforms sufficiently for some to refer to them not as the MacSharry Reforms, after the proposing Commissioner, but the da Cunha Reforms, after the Portuguese Minister.
} 
to force reform of the EU's expensive common agricultural policy ${ }^{7}$ and imposed March 1999 as the deadline for agreement. In so doing, it had reduced its negotiating strength, a position France was able to exploit during the "protracted confrontation"8 between Schröder and Chirac.

The second agreement, by limiting price cuts, limited the extent of the reform, as France desired. Moreover, the smaller increase in cereals payments and consequent larger cut in oilseeds payments helped contain the rise in budget costs. It is also interesting to note that, in the second agreement, the payment for protein crops remained unchanged, leaving a larger premium over other arable crops. France is the largest producer of protein crops in the EU. In the search for compromise prior to the first agreement, Germany had suggested delaying the dairy reform until 2006 and cutting beef prices by $20 \%$ instead of $30 \%$. Both measures had been rejected as undermining the reforms to an unacceptable degree, yet both formed part of the second agreement (the dairy reforms will be introduced from the 2005/06 production year). Both measures were close to the French position and, importantly, of Germany's initial position. This put France in a strong position for the “arm-wrestling” between the two countries (Ackrill 1999). Having a red-green coalition governing Germany, with its different attitude towards the farm lobby and a more positive stance on CAP reform, could not counter the pressures working against radical CAP reform, even though Chirac was reportedly in a minority of one.

These negotiations thus confirm the idea that the speed of CAP reform is determined by the least reform-minded member state. Meunier (1998) argues that in the Uruguay Round negotiations, France forced the Blair House Accord of November

\footnotetext{
${ }^{7}$ Financial Times, January 251999.

${ }^{8}$ Keesing’s Record of World Events, March 1999 (vol. 45, no. 3, page 42864).
} 
1992 to be renegotiated prior to the conclusion of the Round. 'The French government had thus succeeded in making it easier for a defensive member state to capture the negotiating position of the EU ${ }^{9}$. Aided by circumstance, France was able to repeat that in Berlin in 1999.

\section{Possible Directions for Further Reform of the CAP}

Given the pressures on the CAP from further rises in budget costs, enlargement and international commitments, further CAP reform will be needed. Various reform options will be examined briefly to consider their relative merits in allowing the CAP to accommodate enlargement and likely WTO demands.

\section{The Elimination of Price Support}

The European Council reached an agreement retaining price support, with set aside set at $10 \%$. Initially, however, the Ministers of Agriculture cut cereals prices by $20 \%$. This was expected to eliminate price support and the need for set aside and export subsidies under normal market conditions. Further cuts in prices down to the level agreed by the Ministers of Agriculture would provide the CAP with several benefits. There would be a budget saving from the elimination of export subsidies and, in addition, the EU would no longer be bound by GATT/WTO limits on subsidised exports. With this limit removed, intervention could become an outlet of last resort. Given the limit on subsidy expenditures, the elimination of price support would not generate large savings on such spending. EU forecasts for intervention stocks noted earlier, however, suggest that large savings are possible if the EU does not have to resort to intervention in order to respect export subsidy limits.

\footnotetext{
9 Meunier, 1998, p. 208.
} 
Moreover, continued price support could cause difficulties for new member states who are agricultural exporters. Concern has been expressed by Hungary that without the elimination of subsidies, they and other exporters would face a constraint on their exports under a future WTO agreement. Indeed, although the Seattle Ministerial Conference in December 1999 failed to agree an agenda for the Millennium Round talks, the Agriculture Committee indicated export subsidies will be discussed. Only the target - a further reduction or total elimination - remained undecided.

\section{Modulation}

EU enlargement and the extension of the CAP to new member states with large agricultural sectors will have budget implications for the EU. Modulation limits payments to individual farms, so that smaller farms receive 'full' support, whereas the largest farms have payments capped. Whilst this policy will address the political issue of certain farmers receiving extremely large support payments, the overall effect on the budget costs will be limited by the relatively small number of large farms in existing and new member states, unless a severe limit is placed on payments for large farms. Modulation has consistently been opposed by countries such as the UK, France and Denmark and they are likely to be joined by those new member states with larger average farm sizes.

\section{Co-Financing}

Co-financing contains the cost of the CAP to the EU budget by transferring some spending to national budgets. It does not, therefore, reduce the total cost of the policy. Moreover, it could increase policing costs, with national payments monitored to 
ensure they did not distort trade and competition. Co-financing was favoured by Germany as a means of reducing its EU budget contribution but was, unsurprisingly, opposed by countries such as France, Ireland and Spain who are major net recipients of CAP transfers. Given the cost of economic transition, the transfer of some CAP funding to national exchequers could place an excessively large burden on new member states, who may also therefore question co-financing as a suitable direction for CAP reform.

\section{Degressivity}

As a reform option, the UK proposed degressivity prior to the May 1992 CAP reform (Kay, 1998, p. 125). Prior to the 1999 agreement, France proposed cutting payments by $1-3 \%$ per year with exemptions for small farmers, whilst the UK suggested cutting all direct payments by $4 \%$. Estimates indicated cuts of 3\% per year for all payments could save euro 4.6 billion over seven years, whereas annual cuts of $3 \%$ to arable payments and $1 \%$ in other sectors would save about euro 3.1 billion. In its most extreme form, degressivity could eliminate direct payments over a fixed time period.

Degressivity would mean that whilst the cost of enlargement would initially be high, over time the costs would be reduced. Moreover, extending direct payments to new member states could create tensions between those receiving the payments and neighbours who were not. Degressivity would help to limit these potential problems.

\section{Other Concerns over Direct Payments}

With enlargement, of great concern is the budgetary implication of extending the CAP to new member states. The main budget costs of the CAP are the direct payments, given the direction of both the 1992 and 1999 reforms. One way of limiting the cost 
of enlargement is simply not to extend these payments to new member states: "When it comes to enlargement, no major price cuts are expected to take place in the CEC's. On the contrary, for some products accession could well lead to moderate price increases. If this is the case, there will be no economic reason for compensation, at least in the logic of the 1992 reforms” (European Commission 1999, p. 27). Not extending direct payments would also avoid creating tensions in the new member states between those receiving payments and those not, but not extending them would raise other issues.

It would bring the principle of the acquis into question, as well as undermine the 'common' nature of the CAP, something that existing member states have sought to preserve. Moreover, the payments were extended in full to Austria, Finland and Sweden in 1995, even though the level was determined not by the price changes they experienced, but by the price cuts agreed in 1992 by the EC12. Moreover, as world prices rose in the mid 1990s, the level of payment did not change. The "logic of the 1992 reforms” is, therefore, unclear. Is it a specific level of payment to offset specific price cuts, or a general switch in the basis of policy? There is, therefore, a political decision yet to be made. Large budget savings can be realised by not extending the payments to new member states, but the issues this raises may necessitate the full extension of the CAP to all new member states, with other reforms needed to contain the large rise in budget costs.

The WTO negotiations will also challenge the direct payments. Although the payments introduced in 1992 do not break fully the link between support and production (that is, are not fully de-coupled), they go some way to achieving this. For this, they were exempt from the $20 \%$ cut imposed under the Uruguay Round Agreement on support that was not de-coupled. In the WTO negotiations, however, 
other countries will put pressure on the EU to remove the remaining links between support and production, in particular that farmers still have to be producing in order to receive the payments. ${ }^{10}$ The EU has, however, indicated it will defend the payments ${ }^{11}$, as the 1999 agreement will "constitute essential elements in defining the Commission's negotiating mandate for the future multilateral negotiations at the WTO.”12

Unless other countries acquiesce on the EU payments, the direct response would be to alter them so that the remaining links with production are broken. If not, they may be made subject to whatever cut is agreed in the WTO on non de-coupled support. In this context, degressivity offers an interesting option. By reducing the level of payments by a certain percentage over a certain number of years, this is equivalent in essence to what the WTO would impose on non de-coupled support. Degressivity, however, means the cuts are made according to an EU agenda and are not forced on the EU by other countries. This can be very important in 'selling' reforms domestically. It is also important to note that even if the EU does fully de-couple its payments, a complementary policy such as degressivity would still be needed in order to contain the cost of the payments to the EU budget.

\section{Conclusions}

The March 1999 CAP reform reduced price support for arable, beef and dairy producers, replacing this with direct payments. The European Council altered a

\footnotetext{
10 See, inter alia, House of Commons 1998, p. 293 for the views of the Australian government.

11 See, inter alia, European Commission, 1999; Fischler, 1999a, $1999 b$.

12 European Commission 1999, p. 8. According to Agra Europe No. 1867 of 17.9.1999, however, Pascal Lamy, the Trade Commissioner, does not rule out adjusting the payments further.
} 
reform agreed by the Ministers of Agriculture in order to keep CAP spending within 'stabilised' limits. France was able to 'capture' the negotiations and steer reform towards minimal change, also limiting the rise in budget costs. Consequently the reform failed to eliminate price support. Moreover, other reform options were discussed but not agreed upon, with the opposing views of Germany and France on co-financing and degressivity preventing agreement.

Pressure for further reform comes from several directions. Eliminating price support would remove GATT/WTO constraints on subsidised exports, but would not break the link between support and production existing in the current payments. Enlargement will raise the budget cost of the CAP without further reform. Eliminating price support will remove subsidy costs and reduce storage costs, but would result in higher direct payments unless either the price cuts were uncompensated or they were accompanied by other reforms. Of modulation, co-financing and degressivity, it is argued that degressivity is the best accompaniment.

The EU has already indicated an approximate timescale for a 'review' of the CAP agreement. Fischler (1999a, p. 3) indicates that the arable sector will be examined in 2002 when "new decisions may have to be taken”, with the dairy sector looked at in 2003. Both come at about the time the first decisions should be made on enlargement and before the scheduled conclusion of the WTO negotiations. The 1999 reform raises serious questions about the ability of the EU to agree fundamental reforms other than under extreme pressure. With enlargement, WTO negotiations and a limited EU budget, a radical reform is needed. Next time, maintaining the status quo will not be an option. 


\section{References}

Ackrill, R. W., Hine, R. C., Rayner, A. J. and Suardi, M. (1997) 'Member States and the Preferential Trade and Budget Effects of the 1992 CAP Reform: A Note'. Journal of Agricultural Economics, Vol. 48, No. 1, pp. 93-100.

Ackrill, R. W. (1999) 'Les Quinze á Table: Le Grand Marchandage’. Courrier de la Planète, Vol. 51, pp. 16-18.

Agra Europe, various issues.

Beard, N. F. and Swinbank, A. (1998) 'Decoupled Payments, the 'Blue Box' and the CAP'. Mimeo, Department of Agricultural and Food Economics, University of Reading.

Coleman, W. D. and Tangermann, S. (1999) 'The 1992 CAP Reform, the Uruguay Round and the Commission'. Journal of Common Market Studies, Vol. 37, No. 3, pp. 385-405.

Daugbjerg, C. (1999) 'Reforming the CAP'. Journal of Common Market Studies, Vol. 37, No. 3, pp. 407-428.

European Commission (1995) 'Study on Alternative Strategies for the Development of Relations in the Field of Agriculture Between the EU and the Associated Countries with a view to Future Accession of these Countries'. Draft Agricultural Strategy Paper.

European Commission (1997) 'Agenda 2000 - Volume I - Communication: For a Stronger and Wider Union’. COM(97)2000 final.

European Commission (1999) 'The EU Approach to the Millennium Round. Communication from the Commission to the Council and to the European Parliament'. COM(1999)331 final.

European Council (1999) 'Presidency Conclusions: Berlin European Council 24 and 
25 March 1999’. SN 100/99/EN.

The Economist, various issues.

The Financial Times, various issues.

Fischler, F. (1999a) 'The Agenda 2000 Agreement: “Der Himmel über Berlin” or “Sleepless in Seattle”?' Speech to Agra Europe Special Conference, Brussels, 29 June 1999.

Fischler, F. (1999b) 'The European Model of Agriculture - Facing the WTO Acid Test’. Speech to CEA Congress, Verona, 24 September 1999.

House of Commons (1998) CAP Reform: Agenda 2000. Volume II Minutes of Evidence and Appendices. Second Report from the Agriculture Committee, Session 1997/98, HC 311-II. London: HMSO.

Ingersent, K. A., Rayner, A. J. and Hine, R. C. (eds) (1998) The Reform of the Common Agricultural Policy (Basingstoke: Macmillan).

Kay, A. (1998) The Reform of the Common Agricultural Policy: The Case of the MacSharry Reforms (Wallingford: CABI).

Meunier, S. (1998) 'Divided but United: European Trade Policy Integration and E.U.-U.S. Agricultural Negotiations in the Uruguay Round'. In Rhodes, C. (ed.) The European Union in the World Community (London: Lynne Rienner).

Swinbank, A. (1993) 'CAP Reform, 1992’. Journal of Common Market Studies, Vol. 31, No. 3, pp. 359-372. 